\title{
Evaluation of discordant laboratory data in patients with thyroid disorders
}

\author{
J. A. THOMSON, I. T. BOYLE, E. M. MCGIRR, E. M. MACDONALD, \\ J. NICOL, AND J. BROWN \\ From the University Department of Medicine, Royal Infirmary, Glasgow
}

SYNOPSIS The usefulness of the various tests of thyroid function has been evaluated over a threeyear period. It is concluded that an uptake test and estimation of the serum protein-bound radioactive iodine ( $\left.\mathrm{PB}{ }^{131} \mathrm{I}\right)$, supplemented as required by the protein-bound iodine (PBI), remain the best routine tests of thyroid function. Forty-five patients who gave discordant results on these tests over this period have been studied in detail and the value of other tests of thyroid function has been explored.

With the advent of radioisotopes a variety of tests has become available to aid in the diagnosis of thyroid disorders. It must, however, be kept in mind that in the majority of patients the diagnosis of thyrotoxicosis or hypothyroidism can and should be made on clinical grounds. For example, in one series (Wayne, 1960) it was estimated that $85 \%$ of untreated thyrotoxic patients and $81 \%$ of hypothyroid patients could be diagnosed on clinical grounds. In such patients, while confirmatory tests may provide a valuable baseline for future reference, especially in hypothyroidism where lifelong therapy is needed, they are not essential for the initial diagnosis. Unfortunately most publications dealing with the various thyroid tests have concentrated on establishing the feasibility of the test in question and defining the expected ranges in thyrotoxicosis, euthyroidism, and hypothyroidism. The present communication deals with a series of 45 patients seen over a three-year period who presented to us a thyroid diagnostic problem of varying complexity.

\section{METHODS}

Routine ${ }^{131}$ I tests consisted of a 24-hour thyroidal uptake and a 48-hour serum protein-bound ${ }^{131} I$ (PB $\left.{ }^{131} I\right)$. Normal ranges in our laboratory are for a 24-hour uptake between 20 and $50 \%$ dose, and a 48-hour PB $^{131} \mathrm{I}<0.3 \%$ dose/litre plasma.

When indicated, the percentage of the $\mathbf{P B}^{131} I$ which was extractable in butanol $\left(\mathrm{BE}^{131} \mathrm{I}\right)$ was estimated by counting the radioactivity of an aliquot of serum and acidifying with concentrated $\mathrm{HCl}$ to $p \mathrm{H} \mathrm{2}$. The serum was then shaken with an equal volume of butanol/ thiosulphate for five minutes and then centrifuged at $3,000 \mathrm{rpm}$ for five minutes and the supernatant decanted. The precipitate was then counted again. This procedure was performed as a minimum on three occasions but was continued as long as the count rate was falling. The normal range is $>80 \%$ extractable.

The protein-bound iodine was estimated by the method of Farrell and Richmond (1961).

The degree of saturation of the thyroxine-binding globulin (TBG) was estimated by the electrophoretic method of Osorio, Jackson, Gartside, and Goolden (1961) and latterly indirectly by a labelled triiodothyronine resin uptake test $\left(\mathrm{T}_{3}\right.$ resin uptake test $\left.{ }^{1}\right)$.

The ranges found in our laboratory in normal subjects and in unequivocally thyrotoxic or hypothyroid subjects using the above three tests is shown in Table $I$.

The thyroxine suppression test was performed by repeating the ${ }^{131}$ I tests (with appropriate corrections for background activity) after the administration of sodium L-thyroxine $0.1 \mathrm{mg}$ t.i.d. for 10 days.

The thyroid precipitin test was estimated by the method of Anderson, Buchanan, Goudie, and Gray (1962).

It should be noted that not all tests were performed in every patient. In part, this is because the $T_{3}$ resin test was not available at the beginning of the period of study and in other cases because the diagnosis became clear after clinical re-evaluation of the patient, especially with regard to eliciting a history of drug administration or performing a single further test such as finding the presence of serum antibodies to thyroglobulin.

\section{CASE MATERIAL}

The patients studied attended the thyroid clinic at the Royal Infirmary, Glasgow, or had been referred

\footnotetext{
${ }^{1}$ Trisorb test, Abbott Laboratories Ltd.
} 
TABLE I

SUMMARY OF VALUES OF LABORATORY TESTS IN EUTHYROID SUBJECTS AND IN PATIENTS WITH UNEQUIVOCAL THYROTOXICOSIS AND HYPOTHYROIDISM

\begin{tabular}{|c|c|c|c|c|c|c|c|c|c|}
\hline \multirow[b]{2}{*}{ Test } & \multicolumn{3}{|c|}{ No. of Patients } & \multicolumn{3}{|c|}{ Mean Value $\pm 2 S D$} & \multicolumn{3}{|l|}{ Actual Range } \\
\hline & Thyrotoxic & Euthyroid & Hypothyroid & Thyrotoxic & Euthyroid & Hypothyroid & Thyrotoxic & Euthyroid & Hypothyroid \\
\hline PBI $(\mu \mathrm{g} / 100 \mathrm{ml})$ & 203 & 382 & 192 & $\begin{array}{c}10 \cdot 8+6 \cdot 6^{1} \\
-4 \cdot 0\end{array}$ & $5 \cdot 3 \pm 2 \cdot 0$ & $1 \cdot 5 \pm 1 \cdot 7$ & $7 \cdot 0-20 \cdot 0^{1}$ & $3 \cdot 1-7 \cdot 6$ & $0-3 \cdot 7$ \\
\hline $\begin{array}{l}\text { TBG capacity } \\
(\mu \mathrm{g} / 100 \mathrm{ml})\end{array}$ & 7 & 11 & 8 & $18.9 \pm 1.5$ & $23 \cdot 5 \pm 2 \cdot 6$ & $33 \cdot 6 \pm 7 \cdot 2$ & $17 \cdot 6-20 \cdot 0$ & $22 \cdot 0-26 \cdot 0$ & $27 \cdot 4-38 \cdot 0$ \\
\hline $\begin{array}{l}T_{2} \text { resin uptake } \\
\text { test } \\
\text { (\% resin sponge } \\
\text { uptake) }\end{array}$ & 15 & 33 & 12 & $45 \cdot 0 \pm 10 \cdot 0$ & $31 \cdot 5 \pm 4 \cdot 4$ & $21 \cdot 3 \pm 4 \cdot 0$ & $37 \cdot 2-53 \cdot 0$ & $25 \cdot 4-36 \cdot 3$ & $18 \cdot 4-248$ \\
\hline
\end{tabular}

1Thyrotoxic PBI results do not follow a Gaussian distribution but a logarithmic one.

PBI values $>20 \mu \mathrm{g} / 100 \mathrm{ml}$ were recorded as $20 \mu \mathrm{g}$; no attempt was made to achieve greater precision.

to the Radioisotope Unit at the Royal Infirmary. In this unit approximately 3,000 ${ }^{131}$ I tests are performed annually. The period of study is the years 1963-65 inclusive. The series of 45 patients who caused diagnostic difficulty is therefore a highly selected one. Table II indicates the type of patient in whom difficulty arose. These will now be considered in greater detail.

\section{TABLE II}

SUMMARY OF PATIENTS STUDIED WITH CLINICAL STATUS OUT OF KEEPING WITH ${ }^{131}$ I STUDIES OR PBI

\begin{tabular}{|c|c|c|c|c|}
\hline \multirow[t]{2}{*}{ Case } & \multicolumn{3}{|c|}{ Clinical Status } & \multirow[t]{2}{*}{ Eventual Clinical Diagnosis } \\
\hline & Toxic & Euthyroid & Hypothyroid & \\
\hline $1-14$ & - & 10 & 4 & Hashimoto's thyroiditis \\
\hline $15-21$ & 7 & - & 一 & Thyrotoxicosis \\
\hline 22-26 & 2 & 2 & 1 & Treated thyrotoxicosis $\left({ }^{181}\right)$ \\
\hline $27-29$ & 二 & 3 & - & $\begin{array}{l}\text { Treated thyrotoxicosis } \\
\text { (thyroidectomy) }\end{array}$ \\
\hline $30-31$ & 一 & 2 & - & $\begin{array}{l}\text { Treated thyrotoxicosis } \\
\text { (carbimazole) }\end{array}$ \\
\hline 32-35 & 一 & 4 & 一 & Single thyroid nodule \\
\hline 36-38 & - & 3 & 一 & Iodine administration \\
\hline $39-41$ & 一 & 3 & 一 & $\begin{array}{l}\text { Other drugs (excluding iodine } \\
\text { and antithyroid drugs) }\end{array}$ \\
\hline 42-44 & - & - & 3 & Hypopituitarism \\
\hline 45 & - & - & 1 & Dyshormonogenesis \\
\hline Total & 9 & 27 & 9 & \\
\hline
\end{tabular}

CASEs 1-14 This, the largest single group (Table III), consisted of patients in whom eventually the diagnosis of Hashimoto's disease appeared probable. This does not, of course, include the patients in whom the diagnosis of Hashimoto's disease had already been considered by the referring physician, usually because of the consistency of the thyroid gland or associated hypothyroidism. The group under consideration were usually patients in whom ${ }^{131}$ I studies had been performed as part of the investigation of a non-toxic goitre and in whom, usually as a result of a raised $\mathbf{P B}^{131} \mathrm{I}$ out of proportion to the uptake and in the presence of euthyroidism or mild hypothyroidism, the possibility of Hashimoto's disease was raised. The results are summarized in Table III. It is noteworthy that all $\vec{c}$ were women and, with four exceptions, were aged $\stackrel{一}{\complement}$ over 40 years. In four cases there was mild hypothyroidism; the remainder were euthyroid. In the nine cases in which the $\mathbf{P B}^{131} \mathbf{I}$ was high enough to allow a $\mathrm{BE}^{131} \mathrm{I}$ to be estimated, the percentage extractable was less than normal in five. In nine of the 14 cases, the thyroid precipitin test was positive. The PBI was $<3.3 \mu \mathrm{g}$ in seven cases.

The only certain way to diagnose Hashimoto's $\stackrel{\mathbb{Q}}{2}$ disease is by histological examination of the thyroid $\overline{\overrightarrow{ }}$ tissue. However, there is a good correlation between the results of antibody tests and the thyroid histology. We have included several patients in this group because of the overall clinical picture despite the absence of a positive precipitin test and the lack of thyroid histology. One of these patients is described in detail, since she illustrates well the type of problem which we encountered.

Case 5 was a 28-year-old housewife who was referred for evaluation of slight weight loss and a small goitre which had appeared about two years $\frac{D}{O}$ after having had a mitral valvotomy for rheumatic mitral stenosis. Despite a persistent sinus tachy- N cardia, her cardiac status was excellent. She had no other symptoms or physical findings suggestive of $O$ thyrotoxicosis. The ${ }^{131}$ I studies showed a 24-hour $\omega$ uptake of $88 \%$ of the dose and a $\mathrm{PB}^{131} \mathrm{I}$ of $0.40 \%$ of the dose/litre plasma. This was $>90 \%$ butanol extractable. The PBI was $10 \cdot 1 \mu \mathrm{g}$ on three occasions $\mathbb{\Phi}$ and the $T_{3}$ resin uptake test was $29.4 \%$. Because ? of the absence of clinical features of thyrotoxicosis a thyroxine suppression test was performed which showed normal suppression. The thyroid precipitin test and tanned red cell agglutination test was $\stackrel{\unrhd}{\perp}$ negative on two occasions. Because of the small 
TABLE III

SUMMARY OF CASES OF HASHIMOTO'S THYROIDITIS

\begin{tabular}{|c|c|c|c|c|c|c|c|c|}
\hline \multirow[t]{2}{*}{ Case } & \multirow{2}{*}{$\begin{array}{l}\text { Age } \\
(y r)\end{array}$} & \multirow[t]{2}{*}{$\operatorname{Sex}$} & \multicolumn{2}{|l|}{${ }^{101}$ I Studies } & \multirow{2}{*}{$\begin{array}{l}B E^{131} I \\
\left(\% \text { of } P B^{131} I\right)\end{array}$} & \multirow{2}{*}{$\begin{array}{l}P B I \\
(\mu g / 100 \mathrm{ml})\end{array}$} & \multirow{2}{*}{$\begin{array}{l}\text { Thyroid Precipitin } \\
\text { Test }\end{array}$} & \multirow{2}{*}{$\begin{array}{l}\text { Clinical Impression } \\
\text { of Thyroid Status }\end{array}$} \\
\hline & & & $\begin{array}{l}\text { 24-hr Uptake } \\
(\% \text { dose })\end{array}$ & $\begin{array}{l}\text { 48-hr PB } B^{131} I \\
\text { (\% dose/litre plasma) }\end{array}$ & & & & \\
\hline $\begin{array}{r}1 \\
2 \\
3 \\
4 \\
5 \\
6 \\
7 \\
8 \\
9 \\
10 \\
11 \\
12 \\
13 \\
14\end{array}$ & $\begin{array}{l}45 \\
43 \\
47 \\
46 \\
28 \\
54 \\
47 \\
73 \\
37 \\
50 \\
24 \\
40 \\
54 \\
32\end{array}$ & $\begin{array}{l}\mathbf{F} \\
\mathbf{F} \\
\mathbf{F} \\
\mathbf{F} \\
\mathbf{F} \\
\mathbf{F} \\
\mathbf{F} \\
\mathbf{F} \\
\mathbf{F} \\
\mathbf{F} \\
\mathbf{F} \\
\mathbf{F} \\
\mathbf{F}\end{array}$ & $\begin{array}{l}47 \\
55 \\
29 \\
57 \\
88 \\
45 \\
61 \\
55 \\
58 \\
74 \\
25 \\
45 \\
45 \\
42\end{array}$ & $\begin{array}{l}0.83 \\
0.67 \\
0.02 \\
0.67 \\
0.49 \\
\text { Negligible } \\
0.68 \\
\text { Negligible } \\
0.26 \\
0.33 \\
0.55 \\
1.90 \\
\text { Negligible } \\
\text { Negligible }\end{array}$ & $\begin{array}{l}85 \\
70 \\
\text { Not done } \\
83 \\
>90 \\
\text { Not done } \\
62 \\
\text { Not done } \\
60 \\
81 \\
35 \\
66 \\
\text { Not done } \\
\text { Not done }\end{array}$ & \begin{tabular}{r|}
$2 \cdot 6$ \\
$3 \cdot 0$ \\
$3 \cdot 1$ \\
$6 \cdot 3$ \\
$10 \cdot 1$ \\
$2 \cdot 1$ \\
$8 \cdot 0$ \\
$1 \cdot 6$ \\
$5 \cdot 8$ \\
$4 \cdot 8$ \\
$3 \cdot 0$ \\
$6 \cdot 7$ \\
$2 \cdot 1$ \\
$3 \cdot 3$
\end{tabular} & $\begin{array}{l}\text { Positive } \\
\text { Positive } \\
\text { Positive } \\
\text { Positive } \\
\text { Negative } \\
\text { Negative } \\
\text { Positive } \\
\text { Positive } \\
\text { Negative } \\
\text { Negative } \\
\text { Positive } \\
\text { Positive } \\
\text { Negative } \\
\text { Positive }\end{array}$ & $\begin{array}{l}\text { Euthyroid } \\
\text { Euthyroid } \\
\text { Euthyroid } \\
\text { Euthyroid } \\
\text { Euthyroid } \\
\text { ? Hypothyroid } \\
\text { Euthyroid } \\
\text { Hypothyroid } \\
\text { Euthyroid } \\
\text { Euthyroid } \\
\text { Hypothyroid } \\
\text { Euthyroid } \\
\text { ? Hypothyroid } \\
\text { Euthyroid }\end{array}$ \\
\hline
\end{tabular}

TABLE IV

SUMMARY OF CASES OF CLINICALLY THYROTOXIC PATIENTS WITH DISCORDANT RESULTS

\begin{tabular}{|c|c|c|c|c|c|c|c|c|}
\hline \multirow[t]{2}{*}{ Case } & \multirow{2}{*}{$\begin{array}{l}\text { Age } \\
(y r)\end{array}$} & \multirow[t]{2}{*}{ Sex } & \multicolumn{2}{|l|}{${ }^{181}$ I Studies } & \multirow{2}{*}{$\begin{array}{l}T_{1} \text { Suppression } \\
\text { Test }\end{array}$} & \multirow{2}{*}{$\begin{array}{l}P B I \\
(\mu g / 100 \mathrm{ml})\end{array}$} & \multirow{2}{*}{$\begin{array}{l}T_{3} \text { Resin Uptake } \\
\text { Test } \\
(\% \text { resin sponge } \\
\text { uptake })\end{array}$} & \multirow{2}{*}{$\begin{array}{l}\text { TBG Capacity } \\
(\mu g / 100 \mathrm{ml} \text { plasma })\end{array}$} \\
\hline & & & $\begin{array}{l}\text { 24-hr Uptake } \\
(\% \text { dose })\end{array}$ & $\begin{array}{l}\text { 48-hr PB }{ }^{131} I \\
\text { ( } \% \text { dose/litre plasma) }\end{array}$ & & & & \\
\hline $\begin{array}{l}15 \\
16 \\
17 \\
18 \\
19 \\
20 \\
21\end{array}$ & $\begin{array}{l}39 \\
24 \\
59 \\
26 \\
72 \\
41 \\
52\end{array}$ & $\begin{array}{l}\mathbf{M} \\
\mathbf{F} \\
\mathbf{M} \\
\mathbf{F} \\
\mathbf{M} \\
\mathbf{F} \\
\mathbf{F}\end{array}$ & $\begin{array}{l}72 \\
72 \\
30 \\
72 \\
51 \\
66 \\
78\end{array}$ & $\begin{array}{l}\text { Negligible } \\
\text { Negligible } \\
\text { Negligible } \\
1.66 \\
0.68 \\
2.21 \\
1.65\end{array}$ & $\begin{array}{l}\text { No suppression } \\
\text { No suppression } \\
\text { No suppression } \\
\text { No suppression } \\
\text { No suppression } \\
\text { Not done } \\
\text { No suppression }\end{array}$ & $\begin{array}{r}13 \cdot 2 \\
12 \cdot 4 \\
9 \cdot 5 \\
6 \cdot 8 \\
5 \cdot 4 \\
3 \cdot 4 \\
2 \cdot 5\end{array}$ & $\begin{array}{l}- \\
- \\
- \\
\overrightarrow{31} \cdot 4 \\
28 \cdot 8\end{array}$ & $\begin{array}{l}- \\
\bar{z} \\
\overline{18}\end{array}$ \\
\hline
\end{tabular}

size of the thyroid gland and relative lack of symptoms, it was not thought justifiable to proceed to thyroid biopsy. A two-year follow up on this patient has shown no change in the clinical picture or protein-bound iodine. Obviously in this patient the diagnosis of Hashimoto's disease can only be provisional.

CASES 15-21 This group consisted of seven clinically thyrotoxic patients in whom discordant results were obtained. The results of the laboratory tests are detailed in Table IV. In three patients (cases 15-17) the pattern of results was a negligible $\mathbf{P B}^{131} \mathrm{I}$ with raised ${ }^{131} I$ uptake. The PBI was raised in all three cases. In none could the ${ }^{131}$ I uptake be suppressed by thyroxine administration. In three other patients the ${ }^{131}$ I studies were in the thyrotoxic range but the PBI was in the euthyroid range at $6 \cdot 8,5.4$, and $3.4 \mu \mathrm{g}$ respectively. In only the last of these three was the cause known. In this patient the anomalous result was due to the fact that the patient was receiving phenytoin as treatment for major convulsive seizures. In this patient the $T_{3}$ resin uptake test was in the normal range at $31.4 \%$. In two other patients (cases 18 and 19) it is unfortunate that no estimations of the TBG capacity were made.
The remaining patient in this group (case 21) is of some interest. This patient was clinically thyrotoxic and had ${ }^{131}$ I studies in the thyrotoxic range. The PBI, however, was in the hypothyroid range at $2.4 \mu \mathrm{g} / 100 \mathrm{ml}(2.5 \mu \mathrm{g}$ on repeat estimation). There was no obvious lead from the history of why this should be so. She was questioned closely for any history of drug administration, but with the exception of sedative doses of barbiturates (sodium amytal $\frac{3}{4} \mathrm{gr}$ bd) she was receiving no medication. The estimation of the TBG capacity by electrophoresis was low at $18.8 \mu \mathrm{g} / 100 \mathrm{ml}$ and the $\mathrm{T}_{3}$ resin uptake test was in the normal range at $28.8 \%$. Following restoration of euthyroidism by ${ }^{131}$ I therapy the PBI has paradoxically risen and is now at the upper limit of normal at $7.4 \mu \mathrm{g} / 100 \mathrm{ml}$. She has continued to take sodium amytal in the same dosage throughout.

CASES 22-31 These were all patients who had been previously treated for thyrotoxicosis (Table V). In five cases the therapy had been with ${ }^{131}$ I. In patients 22 and 23, although they appeared overall euthyroid, the possibility of residual thyrotoxicosis could not be excluded. The $\mathbf{P B}^{131} \mathrm{I}$ was much higher than is usual in the previously treated patients, in whom in our experience it is usually less than $1.0 \%$ 
TABLE V

\begin{tabular}{|c|c|c|c|c|c|c|c|}
\hline \multirow{3}{*}{ Case } & \multirow{3}{*}{$\begin{array}{l}\text { Age } \\
(y r)\end{array}$} & \multirow{3}{*}{$\begin{array}{l}\text { SUN } \\
\text { Sex }\end{array}$} & \multirow{3}{*}{$\begin{array}{l}\text { AARY OF PREVIO } \\
\text { Therapy }\end{array}$} & \multirow{3}{*}{$\begin{array}{l}\text { TREATED THYROT } \\
\text { Clinical Status }\end{array}$} & IIENTS WITH & PRDANT RESU & \multirow{3}{*}{$\begin{array}{l}P B I \\
(\mu g / 100 \mathrm{ml})\end{array}$} \\
\hline & & & & & \multicolumn{2}{|l|}{${ }^{131}$ I Studies } & \\
\hline & & & & & $\begin{array}{l}\text { 24-hr Uptake } \\
(\% \text { dose })\end{array}$ & $\begin{array}{l}\text { 48-hr } P B^{131} I \\
\text { (\% dose/litre })\end{array}$ & \\
\hline $\begin{array}{l}22 \\
23 \\
24 \\
25 \\
26\end{array}$ & $\begin{array}{l}52 \\
48 \\
53 \\
57 \\
58\end{array}$ & $\begin{array}{l}\mathbf{F} \\
\mathbf{F} \\
\mathbf{F} \\
\mathbf{F}\end{array}$ & ${ }^{131} I$ & $\begin{array}{l}\text { Probably euthyroid } \\
\text { Probably euthyroid } \\
\text { Thyrotoxic } \\
\text { Thyrotoxic } \\
\text { Hypothyroid }\end{array}$ & $\begin{array}{r}47 \\
65 \\
88 \\
56 \\
2\end{array}$ & $\begin{array}{l}1.95 \\
1.99 \\
1.88 \\
3.46 \\
0.01\end{array}$ & $\begin{array}{l}5 \cdot 5 \\
7 \cdot 1 \\
7 \cdot 2 \\
7 \cdot 0 \\
8 \cdot 6\end{array}$ \\
\hline $\begin{array}{l}27 \\
28 \\
29\end{array}$ & $\begin{array}{l}18 \\
47 \\
48\end{array}$ & $\begin{array}{l}\mathbf{F} \\
\mathbf{F} \\
\mathbf{F}\end{array}$ & Thyroidectomy & $\begin{array}{l}\text { Euthyroid } \\
\text { Euthyroid } \\
\text { Euthyroid }\end{array}$ & $\begin{array}{l}59 \\
65 \\
19\end{array}$ & $\begin{array}{l}1.28 \\
0.99 \\
\text { Negligible }\end{array}$ & $\begin{array}{l}7 \cdot 0 \\
4 \cdot 4 \\
4 \cdot 8\end{array}$ \\
\hline 30 & 36 & $\mathbf{F}$ & i & Euthyroid & 91 & 0.25 & $5 \cdot 1$ \\
\hline 31 & 51 & $\mathbf{F}$ & & ? Thyrotoxic & 77 & 0.30 & 5.8 \\
\hline
\end{tabular}

TABLE VI

\begin{tabular}{|c|c|c|c|c|c|c|c|}
\hline \multirow{3}{*}{ Case } & \multirow{3}{*}{$\begin{array}{l}\text { Age } \\
(y r)\end{array}$} & \multirow{3}{*}{ Sex } & \multicolumn{4}{|c|}{ SUMMARY OF CASES OF SINGLE THYROID NODULE } & \multirow{3}{*}{$\begin{array}{l}\text { Thyroid } \\
\text { Scanning }\end{array}$} \\
\hline & & & \multicolumn{2}{|l|}{${ }^{131}$ I Studies } & \multirow{2}{*}{$\begin{array}{l}B E^{131} I \\
\left(\% P B^{131} I\right)\end{array}$} & \multirow{2}{*}{$\begin{array}{l}P B I \\
(\mu g / 100 \mathrm{ml})\end{array}$} & \\
\hline & & & $\begin{array}{l}\text { 24-hr Uptake } \\
\text { (\% dose) }\end{array}$ & $\begin{array}{l}\text { 48-hr PB } B^{131 I} \\
(\% \text { dose/litre plasma) }\end{array}$ & & & \\
\hline $\begin{array}{l}32 \\
33 \\
34 \\
35\end{array}$ & $\begin{array}{l}17 \\
40 \\
67 \\
50\end{array}$ & $\begin{array}{l}\mathbf{F} \\
\mathbf{F} \\
\mathbf{F}\end{array}$ & $\begin{array}{l}46 \\
46 \\
19 \\
19\end{array}$ & $\begin{array}{l}0.64 \\
0.46 \\
1.81 \\
\text { negligible }\end{array}$ & $\begin{array}{l}>80 \\
>80 \\
>80 \\
\text { not done }\end{array}$ & $\begin{array}{l}6 \cdot 4 \\
4 \cdot 6 \\
5 \cdot 4 \\
5 \cdot 4\end{array}$ & $\begin{array}{l}\text { Nodule 'hot' } \\
\text { Nodule 'hot' } \\
\text { Nodule 'cold' } \\
\text { Nodule 'cold' }\end{array}$ \\
\hline
\end{tabular}

dose/litre plasma. The ${ }^{131}$ I uptake was not suppressible with thyroxine. The PBI in both was normal. On follow up they remained euthyroid. In cases 24 and 25 , although the patients were still clinically thyrotoxic and the ${ }^{131} \mathbf{I}$ studies were consistent with this, the PBI levels were in the euthyroid range although towards the upper limit of normal. Unfortunately no estimations of TBG capacity were performed in these patients. Both were treated again with ${ }^{131}$ I and the resulting clinical improvement confirmed our diagnosis of thyrotoxicosis. In the remaining case treated with ${ }^{131}$ I, although the patient was obviously hypothyroid and the ${ }^{131}$ I studies were consistent with this impression, the PBI was elevated to $8.6 \mu \mathrm{g} / 100 \mathrm{ml}$. In view of this, the patient was again questioned with regard to drug administration and eventually admitted to having recently taken a few doses of an iodide-containing cough mixture.

In cases 27 and 28 , who had been treated by thyroidectomy, the ${ }^{131}$ I studies were repeated because of the suspicion of thyrotoxicosis. In both cases the ${ }^{131}$ I studies gave results at the upper limit of normal. The PBI in both cases was in the euthyroid range and subsequent clinical follow up has confirmed this impression. Conversely, in case 29 although the patient appeared euthyroid the ${ }^{131}$ I uptake was just below our normal range. The PBI was normal.
In both cases 30 and 31 where carbimazole hado been recently discontinued (two months and threeo days respectively) and where the referring clinician was anxious about the question of possible active thyrotoxicosis the ${ }^{131}$ I studies were at or just above normal in both, with the PBI levels in the euthyroid range. The overall clinical impression of euthyroidism was confirmed on prolonged clinical surveillance? and in case 31 by repeating the ${ }^{131} \mathrm{I}$ studies after ano interval of two months when the 24-hour uptake was $63 \%$ of the dose and the 48-hour PB $^{131}$ I wasô negligible.

CASES 32-35 In these four cases (Table VI) with a single nodule, the $\mathbf{P B}^{131} \mathrm{I}$ was elevated in three, with a normal $\mathrm{BE}^{131} \mathrm{I}$. In two cases (32 and 33$)$ scanning of the gland showed the presence of $\mathrm{a}^{\circ}$ 'hot' thyroid nodule. In the other two cases (34 and 0 35) the uptake was just below our normal range although associated with a very high $\mathbf{P B}^{131}$ I leveb $(1.81 \%$ of the dose/litre plasma in case 34$)$. It was of interest that in these two patients the uptake which was present was not over the thyroid nodules? but was over the residual thyroid tissue. In all fouro cases the PBI was in keeping with the clinica $\overrightarrow{0}$ impression of euthyroidism.

CASES 36-38 These three patients were referreo for evaluation of a small non-toxic goitre. Difficulty 
arose because of failure to elicit in the initial history the fact that the patient had taken some iodide-containing preparation. In two of these patients this was quickly realized from the combination of a low ${ }^{131}$ I uptake (3\% and $8 \%$ respectively) combined with a grossly raised PBI $(18.6 \mu \mathrm{g}$ and $10.6 \mu \mathrm{g} / 100 \mathrm{ml}$ plasma respectively). In the other patient the situation was more difficult as the ${ }^{131} \mathrm{I}$ studies were in the euthyroid range (24-hour uptake $40 \%$ of the dose and the 48-hour $\mathrm{PB}^{131}$ I negligible). In this case the PBI was raised to $8.0 \mu \mathrm{g} / 100 \mathrm{ml}$. This patient would not admit to any iodide ingestion but the real clue came from the fact that she had chronic bronchitis. After repeated questioning she did admit to taking a few doses of cough mixture about three months before the test was performed.

CASES 39-41 In these three patients other drugs (excluding antithyroid drugs and iodine) interfered with interpretation of the results. In two of these, this was because of administration of oestrogens as part of an oral contraceptive preparation. Both had normal ${ }^{131}$ I uptake $(50 \%$ and $31 \%$ of the dose respectively) with a negligible $\mathbf{P B}^{131} \mathrm{I}$ and raised PBI $(7.6 \mu \mathrm{g}$ and $8.8 \mu \mathrm{g} / 100 \mathrm{ml})$. In one, the $\mathrm{T}_{3}$ resin uptake test was normal $(30.2 \%)$ and in the other it was in the hypothyroid range at $22.5 \%$. The TBG capacity was raised in both cases at 37.0 and 40.0 $\mu \mathrm{g} / 100 \mathrm{ml}$ respectively.

The third case in this group presented a more difficult problem of evaluation. This was a mentally retarded girl of 18 years (case 41) who was referred to the clinic as being possibly hypothyroid. She was of small stature, was moderately obese, and severely mentally retarded. The ${ }^{131} I$ studies were in the euthyroid range (uptake $50 \%$ of the dose and PB $^{131}$ I negligible). However, the PBI was low at $2.7 \mu \mathrm{g} / 100 \mathrm{ml}$. The $\mathrm{T}_{3}$ resin test gave a result at the upper limit of normal $(34 \cdot 3 \%)$. The explanation was that she was receiving phenytoin therapy to control major convulsive seizures.

CASEs 42-44 These three patients with hypopituitarism are of interest. One was a man aged 33 years who had been operated on some years previously for a craniopharyngioma; another was a man of 35 years who had had a chromophobe adenoma removed; and the third case in this group was a boy of 13 years with idiopathic hypopituitarism. All three had clinical secondary hypothyroidism. The ${ }^{131}$ I uptakes were normal $(40 \%, 49 \%$, and $33 \%)$ with negligible $\mathrm{PB}^{131} \mathrm{I}$, but the low PBI levels $(2 \cdot 3,1 \cdot 6$, and $3 \cdot 2 \mu \mathrm{g} / 100 \mathrm{ml}$ ) were in keeping with the patients' clinical status.

CASE 45 This last patient was a girl of 11 years who was referred to the clinic because of a large goitre. There was no family history of thyroid enlargement. Although she was clinically euthyroid or mildly hypothyroid the ${ }^{131}$ I studies were in the thyrotoxic range (uptake $81 \%$ of the dose, $\mathrm{PB}^{131} \mathrm{I} 0.75 \%$ of the dose/litre plasma). The $\mathrm{BE}^{131} \mathrm{I}$ was $78 \%$ of the PB ${ }^{131} \mathrm{I}$. The PBI was $2 \cdot 1 \mu \mathrm{g} / 100 \mathrm{ml}$ and the TBG capacity was in the hypothyroid range at $30.0 \mu \mathrm{g} / 100 \mathrm{ml}$, as was the $\mathrm{T}_{3}$ resin uptake test at $20 \%$. Biochemical studies on the resected gland showed that she had a dyshormonogenetic goitre of the iodoprotein type (McGirr, Hutchison, Clement, Kennedy, and Currie, 1960).

\section{DISCUSSION}

The patients reported in this paper do not fall into any homogenous group. The largest single group was those patients who were thought to have Hashimoto's disease. This is a condition in which anomalous ${ }^{131} \mathrm{I}$ results have been recognized for some time (Murray and McGirr, 1960). In the cases under discussion, however, it should be emphasized that these were cases in which the diagnosis was not entertained by the referring clinician. Once the possibility had been raised (usually by the elevated $\mathbf{P B}^{131} \mathbf{I}$ often combined with a lowered PBI) the diagnosis could be simply made by estimation of the serum antibodies. This would seem to be the investigation of choice in the middle-aged woman with a raised PB $^{131}$ I without obvious cause. It must be admitted, however, that there were some cases, for example case 5 , in which there is still doubt about the final diagnosis.

The seven cases of thyrotoxicosis are of interest. In the three cases with the negligible PB $^{131}$ I the only possibly explanation is that the intrathyroidal turnover of iodine is unusually slow. We have seen this pattern of results in three subsequent patients after the period under consideration. In the group of four with the low or normal PBI the explanation was only clear in one (case 20) who was receiving phenyton, which is recognized as depressing the PBI by occupying the binding sites on the TBG molecule (Oppenheimer and Tavernetti, 1962). A similar false low PBI in a euthyroid patient is illustrated by case 41 . In one other patient (case 21) the low PBI when thyrotoxic and the return to normal levels when euthyroid is inexplicable. Cases of thyrotoxicosis in which the PBI has been low despite clinical thyrotoxicosis have been described by Cavalieri (1961). This has been attributed to congenitally low levels of circulating TBG. This explanation would seem unlikely in our patient in view of the response of the PBI to the 
control of the thyrotoxic state. Our patient had no close relatives available for examination. It is worthwhile emphasizing that in all of this group the diagnosis of thyrotoxicosis was finally confirmed by observing the clinical response to antithyroid therapy.

The difficulty in interpreting ${ }^{131}$ I studies when there is only a small rapidly turning over thyroidal iodine pool is well recognized. This occurs after treatment of thyrotoxicosis with ${ }^{131}$ I, thyroidectomy, or antithyroid drugs. In this latter group a temporary state of iodine deficiency is induced (Alexander, Harnden, Koutras, and Wayne, 1965). In all of this group of previously treated thyrotoxic patients most help was obtained from estimation of the protein-bound iodine. In two cases, however, the opposite problem was present of patients treated with ${ }^{131}$ I who were still clinically thyrotoxic (and who responded clinically to anti-thyroid therapy) who had ${ }^{131}$ I studies consistent with thyrotoxicosis but PBI in the euthyroid range. In these two cases, however, we lack the data to make any valid comment on the TBG levels.

Cases of non-toxic goitre with a single 'hot' nodule may also have a small intrathyroidal iodine pool and this occurred in patients 32 and 33. In cases 34 and 35 the uptakes were rather low although associated, in case 34 , with a greatly elevated $\mathbf{P B}^{131} \mathrm{I}$. In both these cases the scan showed no uptake over the nodule. The most reasonable explanation would seem to be that there was only a small rim of normally functioning thyroid tissue around the nodule and this was giving the pattern of results more usually associated with a 'hot' nodule.

The three patients to whom iodine had been administered illustrate the extreme importance of getting a good history of the drugs which the patient is taking or has taken in the recent past. This is sometimes not as simple in practice as it theoretically should be. During the period of study we, of course, saw a much larger number of patients in whom such a history of iodine administration was obtained and we either postponed the tests for a suitable interval or the $T_{3}$ resin uptake test was used, this being the most suitable test as it is not affected by iodine administration. In case 38 difficulty arose because there was apparently only enough residual iodine to affect the PBI without influencing the ${ }^{131}$ I uptake.

Similarly, in cases 39 and 40 the history of administration of oral contraceptive drugs was overlooked. The administration of an oestrogencontaining drug was suspected on noting the combination of a normal uptake and an elevated PBI with elevated TBG capacity. In one of these cases the $T_{3}$ resin uptake test was as expected falsely low but in the other it was normal. It is worthwhile noting that in one series of $T_{3}$ resin을 tests in pregnancy (Clark and Horn, 1965), where $a \vec{\Rightarrow}$ similar alteration of TBG capacity exists, the $T_{3} \stackrel{\text { ? }}{?}$ resin test was in the normal range in $8.7 \%$ of cases. With the increasing use of oral contraceptive agents $\frac{\bar{c}}{\bar{c}}$ this group is becoming more important as a fallacy of the protein-bound iodine test.

The three patients with hypopituitarism arew interesting. Again it must be emphasized that during the three-year period of study we encounteredseveral other hypopituitary patients who gave thew more usual results of a low ${ }^{131}$ I uptake and protein $?$ bound iodine. The explanation of the anomalous? 131I uptakes in our patients who were clinically. hypothyroid is either that the thyroid had retained $\odot$ some autonomous function, which is recognizedr as occurring in animals, which, despite having had hypophysectomy performed, can still respond to iodine deficiency by increased thyroid function (Means, De Groot, and Stanbury, 1963), or more probably that a minimal amount of TSH was being secreted which enabled the thyroid to trap a normato proportion of the test dose but which was not enougho consistently to produce sufficient thyroxine secretion to maintain clinical euthyroidism. The discrepancys of a normal ${ }^{131}$ I uptake with a low PBI in hypo pituitarism has been previously noted (Christy 1960) but is not apparently widely recognised.

In the final patient, case 45 , the absence of family history of goitre and the absence of significan hypothyroidism, although not exclusive, are points against the suspected diagnosis of dyshormono genesis. The pattern of results, however, made this diagnosis clear and this was confirmed by studies? in vitro upon the resected thyroid tissue, whicks showed that she was producing an abnormat. iodoprotein (McGirr et al, 1960).

One point which is well brought out by these studies is that there is no single ideal thyroid test af present in current use. In practice the tests used are a compromise between a wide battery of tests. for all patients, covering many aspects of thyroid function, and a selective procedure designed to achieve a correct diagnosis in the majority of patients with minimal investigation. Nowadays a centres dealing with large numbers of thyroid cases should have access to an isotope laboratory cono taining at least an uptake counter and a well typ $\bar{\Phi}$ scintillation counter. It is probable that some forn of uptake measurement together with an estimation of the $\mathrm{PB}^{131} \mathrm{I}$ at 48 hours will remain the bes routine tests of thyroid function. Indeed it was interesting in the present series (for example cases 20,21 , and 39-41) where the peripheral transo port of the thyroid hormone was altered that the 
${ }^{131}$ I studies gave a truer reflection of the clinical status than did the other tests.

The recently suggested combination of an uptake measurement and a $T_{3}$ resin uptake test (Carter, 1966) would seem to us unsatisfactory in that having given the patient a dose of radioactivity one might as well proceed to estimate the $\mathbf{P B}^{131} \mathrm{I}$.

If tests other than ${ }^{131}$ I studies are to be used the PBI is the most useful, especially in our experience in patients previously treated for thyrotoxicosis. The $T_{3}$ resin uptake test is an alternative but in the form of the Triosorb test it is rather expensive and the test kit has to be used within a short time of receipt. It is, however, of definite value in the investigation of a patient known to have taken iodides in whom doubt exists as to the clinical thyroid status and in whom an urgent answer is necessary. It is also of value in conditions of abnormal thyroxine binding. In this latter context the 'free' thyroxine index (Clark and Horn, 1965) has been used. This is an arbitrary product of the $P B I$ and $T_{3}$ resin uptake. The value of the test is that in conditions such as pregnancy where the PBI and TBG capacity alter, they are changed in opposite directions thereby cancelling out in the euthyroid subject. We have insufficient data of our own to comment on the usefulness of this test, especially in states of altered TBG capacity in the presence of clinically altered thyroid function, but it is of interest to note that in neither of our two thyrotoxic patients with altered TBG capacity (cases 20 and 21) would the correct clinical diagnosis have have been made on the basis of these two tests alone.

A direct measurement of the free thyroxine (Oppenheimer, Squef, Surks, and Hauer, 1963) may well prove to be an extremely important test but is at present too cumbersome for routine use.

These results seem to us worth reporting to illustrate the type of clinical problem encountered at a thyroid clinic and to illustrate how the various laboratory tests may help in achieving the correct diagnosis where clinical doubt exists.

\section{REFERENCES}

Alexander, W. D., Harnden, R. McG., Koutras, D. A., and Wayne, E. (1965). Lancet, 2, 866.

Anderson, J. R., Buchanan, W. W., Goudie, R. B., and Gray, K. G. (1962). J. clin. Path., 15, 462.

Carter, R. A. (1966). Ibid., 19, 128.

Cavalieri, R. R. (1961). J. clin. Endocr., 21, 1455.

Christy, N. P. (1960). In Clinical Endocrinology, edited by E. B. Astwood. p. 56. Grune and Stratton, New York.

Clark, F., and Horn, D. B. (1965). J. clin. Endocr., 25, 39.

Farrell, L. P., and Richmond, M. H. (1961). Clin. chim. Acta, 6, 620. McGirr, E. M., Hutchison, J. H., Clement, W. E., Kennedy, J. S., and Currie, A. R. (1960). Scot. med. J., 5, 189.

Means, J. H., De Groot, L. J., and Stanbury, J. B. (1963). The Thyroid and its Diseases, 3rd ed., p. 87. McGraw-Hill, New York.

Murray, I. P. C., and McGirr, E. M. (1960). Brit. med. J., 1, 838.

Oppenheimer, J. H., and Tavernetti, R. R. (1962). J. clin. Invest., 41. 2213.

—, Squef, R., Surks, M. I., and Hauer, H. (1963). Ibid., 42, 1769.

Orsorio, C., Jackson, D. J., Gartside, J. M., and Goolden, A. W. G. (1961). Clin. Sci., 21, 355.

Wayne, E. J. (1960). Brit. med. J., 1, 1. 